8. Клейн Р. М., Клейн Д. Т. Методы исследования растений. Москва. 1974. 527 с.

9. Смит У. Х. Лес и атмосфера. Москва. 1985. 429 с.

10. Ставрова Н. И. Влияние атмосферного загрязнения на возобновление хвойных пород // Лесные экосистемы и атмосферное загрязнение. Ленинград. 1990. С. 121-144.

11. Юсыпива T. И. Ростовые показатели стеблей самосева древесных пород в условиях техногенных эмиссий $\mathrm{SO}_{2}$ и $\mathrm{NO}_{2} / /$ Современные научные исследования в садоводстве. Ялта. 2000. Ч. 1. С. 178-183.

12. Antonova G.F., Stasova $\boldsymbol{V}$. $\boldsymbol{V}$. Seasonal distribution of processes responsible for radial diameter and wall thickness of larch (Larix sibirica Ldb.) tracheids // Improvement of larch (Lar$i x$ sp.) for better growth, stem form and wood quality Proceedings of an International Symposium. Gap (Hautes-Alpes). France. 2002. S. 369-377.

13. Hiroshi Yra. Comparative Ecophysiology of Larix kaempferi (Lamb.) Carr. and Abies veitchii LindL. II. Mechanisms of Higher Drought Resistance of Seedlings of L. kaempferi as compared with $A$. veitchii // Ecol. Res. 1989. 4. 3. P. 351-360.

14. Usipiva T. Root morphometric characteristics of the woody plant seedlings under the conditions of the and industrial pollution // Salaš P.: Proceedings of $9^{\text {th }}$ International Conference of Horticulture. Sept. $3^{\text {th }}-6^{\text {th }}$ 2001. Lednice, Czech Republic. ISBN 80-7157-524-0. Vol. 3. P. 680-684.

Надійшла до редколегії 10.05.2016

УДК $598.112+574.476$

В. Я. Гассо

Дніпропетровський національний університет імені Олеся Гончара

\title{
РИЙНА ДІЯЛЬНІСТЬ ПРУДКОЇ ЯЩІРКИ В УМОВАХ ПРИСАМАР'Я
}

Представлено результати досліджень обсягів рийної діяльності прудкої ящірки у степовому та лісовому (суховатий бір) біогеоценозах Присамар'я. Визначено глибину занурення та довжину ходу нір, об'см та масу винесеного на поверхню грунту як з однісї нори, так й у перерахунку на гектар. Встановлено, що нори прудкої ящірки можуть відрізнятися за будовою у двох типах біогеоценозів. Об'єм та маса грунту, який виноситься з однісї нори на поверхню, більші у бору на 20 \% та 280 \% відповідно. Однак у перерахунку на гектар лише маса винесеного грунту достовірно більша в лісовій екосистемі.

Ключові слова: плазуни, функціональна роль, нори, грунт.

В. Я. Гассо

Днепропетровский нащиональный университет имени Олеся Гончара

\section{РОЮЩАЯ ДЕЯТЕЛЬНОСТЬ ПРЫТКОЙ ЯЩЕРИЦЫ В УСЛОВИЯХ ПРИСАМАРЬЯ}

Представлены результаты исследований объемов роющей деятельности прыткой ящерицы в степном и лесном (суховатый бор) биогеоценозах Присамарья. Определены глубина и длина хода нор, объем и масса вынесенной на поверхность почвы как из одной норы, так и в пересчете на гектар. Установлено, что норы прыткой ящерицы могут отличаться по строению в исследованных типах экосистем. Объем и масса почвы, которая выносится из одной норы на поверхность, больше в бору на $20 \%$ и $280 \%$ соответственно. Однако в пересчете на гектар только масса вынесенной почвы достоверно больше в лесной экосистеме.

Ключевые слова: пресмыкающиеся, функциональная роль, норы, почва.

(C) В. Я. Гассо, 2016 


\section{Y. Gasso}

Oles Honchar Dnipropetrovsk National University

\section{DIGGING ACTIVITY OF SAND LIZARD IN THE SAMARA RIVER AREA}

The research results of the digging activity of sand lizard Lacerta agilis Linnaeus, 1758 in the steppe and forest ecosystems are presented. The study was conducted in the Samarsky Forest at the sample plots of O.L. Belgard Prysamarsky International Biosphere Station in 2009-2011 (Dnipropetrovsk oblast, Ukraine). The depth of burrow, the length of tunnel, the volume and weight of the ground excavated on the surface were determined both for a single burrow and per hectare. The soil of the steppe virgin land is a chernozem. Forest ecosystem is a dryish pine forest with the sandy pinery-sod soil. To study the burrows that are guaranteed to dig by a sand lizard, two adult lizards (male and female) were settled on the plot of $4 \times 4 \mathrm{~m}$ enclosed by the plastic fence of $0.5 \mathrm{~m}$ height. The other holes of a similar architecture were studied. In addition, the architecture of lizards' holes is rather different from the rodents' burrows and characterized by its simplified structure. 14 holes on the steppe virgin land and 9 holes in the dryish pinery were studied. The depth and length of the holes were determined using a metal tape while digging holes up. The structure of the lizard burrows were studied by producing the gypsum casts. All the examined holes were settled by lizards. At the steppe plots the lizard burrows are more various in structures. The deepest burrow that has been identified was $28 \mathrm{~cm}$, but the longest tunnel was $64 \mathrm{~cm}$. Most of the holes ( $86 \%$ ) had only one entrance and one small lateral blind hole. Among surveyed holes only one had two entrances and one burrow - three. $14 \%$ of the studied burrows had no lateral holes. In the pine forest the deepest hole was $42 \mathrm{~cm}$ and the longest tunnel was 61 $\mathrm{cm}$. The majority of burrows (89 \%) had only one entrance, but only one burrow (11\%) had two entrances as well as only one burrow was "equipped" by a small lateral blind hole. All the other burrows in the pinery did not have lateral holes at all. There were no differences between the two studied types of ecosystems in the tunnel length and depth of the dug burrows. But the soil volume and mass removed from one hole on the surface is more in the dryish pine forest by $20 \%$ and $280 \%$ (due to its high volume weight), respectively. The digging of one burrow in the pinery requires excavating 2.8 times more soil mass than in the steppe despite the almost identical tunnel lengths. Taking into account the number of the sand lizard burrows per hectare it was found that the total volumes of excavated soil in both surveyed ecosystems are nearly identical. At the same time, the weight of removed ground from the dug burrows was 2.2 times higher in the dryish pinery.

Keywords: reptiles, functional role, burrows, soil.

Плазуни відіграють значну роль у формуванні біорізноманіття як функціонального компонента екологічних систем та у різних біогеоценотичних процесах, більшість яких спрямована на підтримання екологічної стійкості екосистем. Особливо зростає роль цих тварин в умовах степових лісів, де вони утворюють захисний бар'єр проти розповсюдження комах-фітофагів (В. Л. Булахов та ін., 2007).

Ареал прудкої ящірки (Lacerta agilis Linnaeus, 1758 (Reptilia, Squamata)) охоплює декілька природних зон, найбільш оптимальною із яких є зона степу. Так як прудка ящірка є евритопним видом, вона заселяє багато біотопів, обираючи в них ті місця, у котрих $є$ відповідна екологічна ніша: достатня кількість корму, сховищ, необхідна вологість, освітленість і т. п. У цих місцях ящірка займає територію, розміри якої зазвичай не перевищують 300 м² (В. Л. Булахов та ін., 2007, Ю. В. Кармишев, 2002).

У межах індивідуальної території ящірки мають тимчасові та постійні сховища різного типу. Найбільш звичними є нори. Ящірки часто оселяються у вільних норах гризунів, але риють і самі (В. І. Таращук, 1959).

За класифікацією функціональної ролі тварин в екосистемах (В. Л. Булахов, О. С. Пахомов, 2010) їх рийна активність забезпечує три основних види діяльнос- 
ті: проникний, що призводить до зменшення твердості і щільності грунтів, збільшення аерації, вологості, водопроникності і т.п.; виносний - винесення на поверхню глибинних горизонтів грунту, змішування різних генетичних рівнів грунтового покриву, утворення елементів нано- і мікрорельєфу і т.п.; та розпушувальний, який забезпечує перемішування верхніх шарів грунту, переміщення гумусу в більш глибинні горизонти, прискорює мінералізацію та підвищує біологічну активність грунтів. Для прудкої ящірки найбільш характерними $є$ перші два види впливу.

Метою цієї роботи є оцінка обсягів рийної активності прудкої ящірки у двох типах біогеоценозів, де цей вид досягає найбільшої чисельності у Присамар'ї (В. П. Гончарова, 1961, В. Л. Булахов, Н. Ф. Константинова, 1977, В. Л. Булахов, 2000, В. Я. Гассо, 2009).

Матеріали і методи досліджень. Дослідження проводили на пробних площах (п/п) біогеоценотичного профілю Присамарського міжнародного біосферного стаціонару ім. О. Л. Бельгарда у складі Комплексної експедиції Дніпропетровського національного університету ім. О. Гончара впродовж 2009-2011 років. Район дослідження розташований у північній підзоні зони справжнього степу (Физико-географическое, 1968, Фізична, 1992) Використовували стандартні методи в екології наземних хребетних тварин (Г. А. Новиков, 1949). Рийну діяльність досліджували у типових для прудкої ящірки біогеоценозах - на степовій цілинці (пробна площа 201) та в сухуватому бору на арені (п/п 212).

Степова цілинка (п/п 201). Тип грунту: чорнозем звичайний, карбонатний, малогумусний, середньосуглинистий на лесоподібних суглинках (Н. А. Белова, А. П. Травлеев, 1999). Сольовий профіль грунтів степової цілинки відрізняється невисоким вмістом водорозчинних солей. Кількість сухого залишку коливається від 0,06 до 0,18 \% (Ю. І. Грицан, 2000). У трав'яному покриві панують багаторічники, ксерофіти і мезоксерофіти, мезотрофи, створюючи три яруси біогеогоризонтів. У рослинному покриві переважають шавлія степова (Salvia stepposa), деревій звичайний (Achillea millefolium), астрагал шиловидний (Astragalus subulatus), люцерна романська (Medicago romanica), молочай степовий (Euphorbia stepposa). Загальне покриття травостоєм - $90 \%$.

Сухуватий бір (п/п 212). В умовах степової зони України аренні ліси розташовані на других піщаних терасах річок. Завдяки позазаплавному положенню арени знижується роль факторів заплавності та алювіальності і посилюється значення факторів зонального порядку. Грунт - дерново-боровий. Зволоження атмосферне. Рослинність аренних місцезростань не утворює зімкнутого покриву. Травостій характеризується наявністю таких видів, як чаполоч пахуча (Hierochloe odorata), кипець сизий (Koeleria glauca), костриця Беккера (Festuca beckeri) та інші. У суховатому борі спостерігається прогрівання лісової підстилки, яка $\epsilon$ в даному типі лісу активним шаром, що визначає теплообмін верхнього горизонту грунту й повітря (Ю. Е. Алексеев и др., 1986, А. Л. Бельгард, 1950, 1971). Однак прогрівання травостою та підстілки у степу набагато сильніше.

Для дослідження нір, які гарантовано вириті прудкою ящіркою, двох дорослих ящірок (самець та самка) випускали на ділянку $4 \times 4$ м, огороджену пластиковим парканчиком висотою 0,5 м. Також досліджували інші нори, які виявилися за архітектурою схожими з виритими на експериментальній ділянці. До того ж архітектура нір ящірок відрізняється від нір гризунів своєю спрощеною структурою. Усього досліджено 14 нір на степовій цілинці та 9 нір у суховатому бору. Глибину занурення та довжину ходу нір визначали за допомогою металевою рулетки при розкопуванні нір.

Для визначення об'єму рийної діяльності ящірок визначали структуру та об'єм нір за допомогою гіпсових зліпків. Для цього готували гіпсовий розчин із приблизного розрахунку 1 кг алебастру на 1 л води. Слід мати на увазі, що гіп- 
совий розчин має здатність швидко гуснути, тому треба готувати його в невеликій кількості, постійно помішуючи. Цим розчином обережно заливали досліджувані нори ящірок. За необхідності нору поступово розкопували та доливали розчин поки не досягали дна. При виявленні віднорка проводили таку саму процедуру. Залиту гіпсовим розчином нору залишали на дві - чотири доби залежно від вологості грунту. Після цього гіпсовий зліпок обережно викопували. Якщо після розкопки виявляли частину нори, яка не була залита гіпсом, проводили додаткову заливку цієї частини нори. Після чого знову залишали гіпс до висихання та викопували. Після отримання гіпсового зліпку нори, його очищують та вимірюють: визначають загальну довжину нори, глибину залягання та об' $є$ м гіпсового зліпку. Об'єм зліпку вираховували за законом Архімеда занурюванням зліпку у воду. Таким способом зроблено по п'ять гіпсових зліпків нір у кожному з досліджуваних біогеоценозів.

Результати і їх обговорення. Нори мають велике значення в житті плазунів, оскільки $є$ найважливішим типом схованки. В умовах Присамар'я прудка ящірка в якості захистку використовує щілини та пустоти у грунті, особливо під корінням дерев, густу траву та гілки чагарників. Втім, найбільше значення мають постійні нори.

Вважається, що у степових екосистемах з великою кількістю гризунів прудка ящірка рідко риє нори сама, а значно частіше заселяє нори, які залишили саме гризуни (L.J. Vitt, J. P. Caldwell, 2013). Молоді тварини використовують навіть нори крупних жуків (наприклад, чорнотілок). За нашими спостереженнями, в умовах Присамар'я прудка ящірка часто риє нори сама. Це також доводить їх простіша, у порівнянні з норами гризунів, будова.

На степовій цілинці нори прудких ящірок різноманітні. Найбільша глибина нори, що була визначена, склала 28 см, а довжина ходу - 64 см (рис. 1). Усі нори, які досліджували, були заселені. Більшість нір (86 \%) мали лише один вихід та один невеликий віднорок. Серед досліджених нір 7 \% мали по два виходи та стільки ж - по три виходи. 14 \% 3 досліджуваних нір віднорків не мали взагалі.
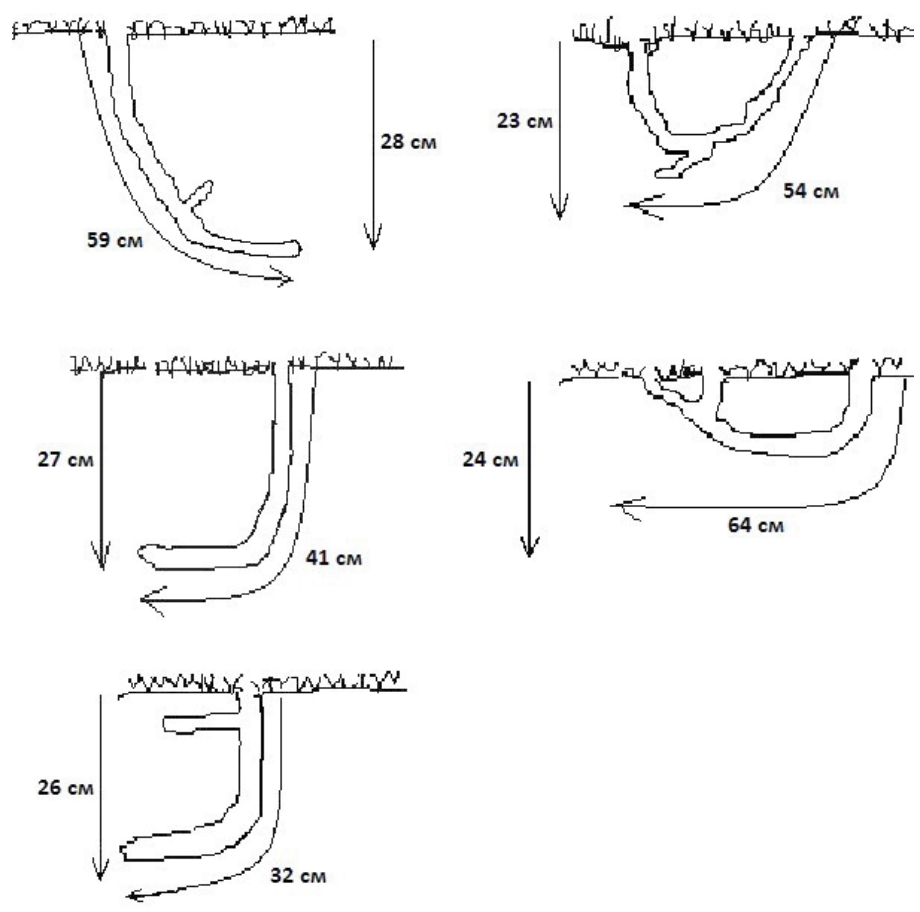

Рис. 1. Схеми нір прудкої ящірки, що розташовані на ділянці степової цілинки у Присмар'ї (пробна площа 201) 
У суховатому бору найбільша глибина нори склала 42 см, а зареєстрований найдовший хід - 61 см (рис. 2). Усі досліджувані нори також були заселені. Переважна більшість нір (89 \%) мали лише один вихід і лише одна нора (11\%) мала два виходи та одна нора - невеликий віднорок. Усі інші нори на цій ділянці віднорків не мали взагалі.

Таким чином, із представлених схем видно, що нори ящірок у степових та лісових біоценозах дещо відрізняються за будовою. Так, на арені вони мають вигляд довгих коридорів зазвичай без віднорків та з одним виходом. За даними B. I. Таращука (1959), в лісових біоценозах нори можуть досягати 70 см, а за даними В. А. Кутузової - навіть до 200 см (цит. по Прыткая...., 1976).

У степу будова нір буває складнішою. Довжина та складність архітектури нори (кількість виходів та наявність віднорків) можуть залежати від тривалості використання сховища. У цьому сенсі, більш закріплений чорнозем степової цілинки може виявитися стабільним, а нори - довгоіснуючими, на відміну від пісків арени з можливістю частішого руйнування нір.
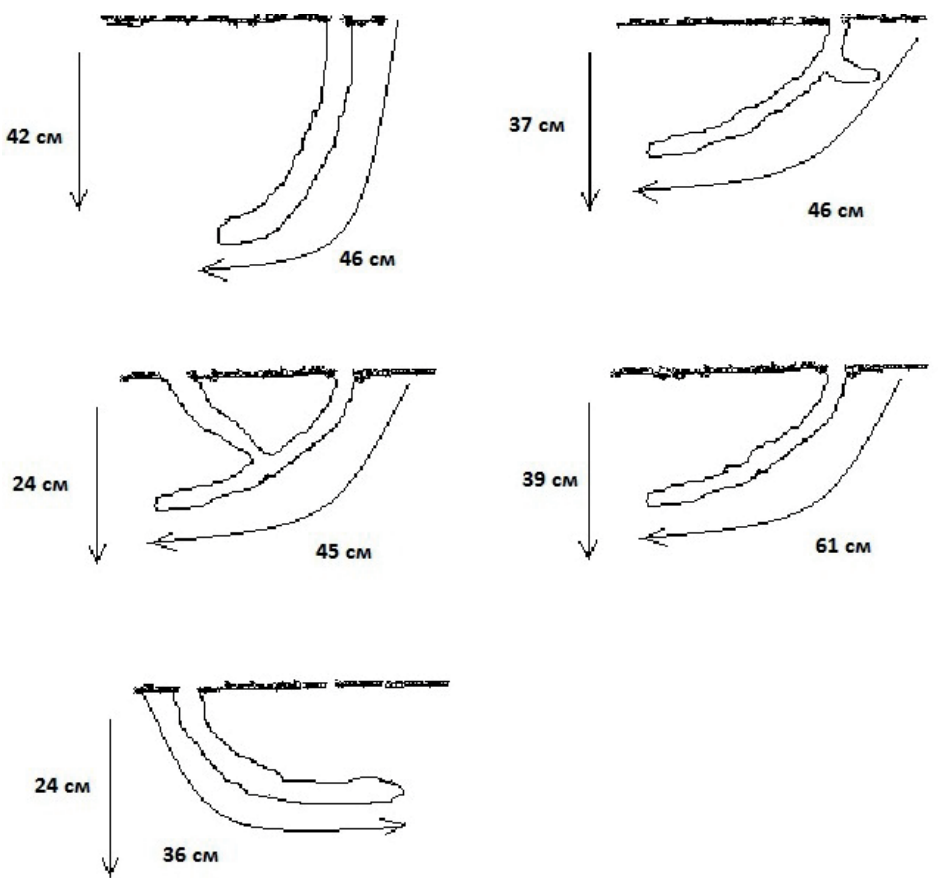

Рис. 2. Схеми нір прудкої ящірки, що розташовані на ділянці суховатого бору в Присмар'ї (пробна площа 212)

При визначенні об'ємів рийної діяльності прудкої ящірки виявилося, що для степової цілинки середній об'єм винесеного грунту на поверхню 3 нижніх горизонтів склав $299 \mathrm{~cm}^{3}$ з однієї нори, а 3 аренного бору -377 см$^{3}$ (табл. 1).

Такі відмінності між норами ящірок у двох біогеоценозах можуть бути пов'язані з різним механічним складом грунтів. Піски на арені більш сипучі, тому при ритті нори ящірка легше виносить більший об'єм грунту навіть при майже однаковій довжині нір в обох біотопах.

Зважаючи на те, що об'ємна вага супіщаного грунту суховатого бору скла-

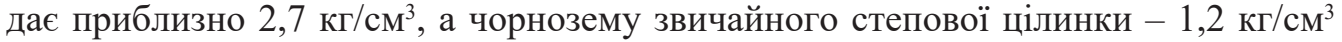
(Н. А. Белова, А. П. Травлеев, 1999, Ю. І. Грицан, 2000), ми визначили масу винесеного ящірками грунту під час риття нір. Виявилося, що риття однієї нори у суховатому бору вимагає винесення на поверхню у середньому в 2,8 раза більшої 
маси грунту, ніж на степовій цілинці (табл. 1), і це при майже однаковій довжині ходу.

Таблиия 1

Характеристика нір прудкої ящірки в умовах Присамар'я

\begin{tabular}{|c|c|c|c|c|}
\hline $\begin{array}{c}\text { Показник } \\
\text { для усередненої нори }\end{array}$ & Біогеоценоз & $n$ & $M \pm S D$ & $\lim$ \\
\hline \multirow{2}{*}{ Глибина занурення, см } & степова цілинка & 14 & $26,1 \pm 2,17$ & $23-30$ \\
\hline & суховатий бір & 9 & $34,4 \pm 6,91$ & $24-42$ \\
\hline \multirow{2}{*}{ Довжина ходу, см } & степова цілинка & 14 & $49,8 \pm 10,8$ & $32-66$ \\
\hline & суховатий бір & 9 & $48,1 \pm 7,57$ & $36-61$ \\
\hline \multirow{2}{*}{$\begin{array}{l}\text { Об’єм винесеного грунту, } \\
\text { см }^{3}\end{array}$} & степова цілинка & 5 & $299 * \pm 31,9$ & $233-387$ \\
\hline & суховатий бір & 5 & $377 \pm 43,5$ & $286-486$ \\
\hline \multirow{2}{*}{ Маса винесеного грунту, г } & степова цілинка & 5 & $359 * \pm 71,9$ & $279-464$ \\
\hline & суховатий бір & 5 & $1010 \pm 249$ & $772-1310$ \\
\hline
\end{tabular}

Примітка. М - середнє значення, SD - стандартне відхилення, * $-\mathrm{P}<0,05$.

Ми визначили також середню щільність нір ящірки прудкої в досліджуваних екосистемах. Показник щільності для обох біотопів не має достовірних відмінностей (табл. 2), хоча тенденція до більшого числа нір у степу добре прослідковується. Для чорноземного степу характерна наявність у грунті гумусу, тоді як арена - це піщана тераса. Піщані грунти сипучі, тому нори ящіркам важче рити на степовій цілинці, проте ці нори більш довготривалі.

Таблиия 2

\section{Обсяги рийної діяльності прудкої ящірки в умовах Присамар'я}

\begin{tabular}{|c|c|c|c|}
\hline Показник & Біогеоценоз & $M \pm S D$ & $\lim$ \\
\hline \multirow{2}{*}{ Щільність нір, шт./га } & степова цілинка & $481 \pm 103$ & $298-671$ \\
\cline { 2 - 4 } & суховатий бір & $362 \pm 133$ & $127-596$ \\
\hline \multirow{2}{*}{ Об’єм винесеного грунту, м³/га } & степова цілинка & $0,149 \pm 0,087$ & $0,071-0,261$ \\
\cline { 2 - 4 } & суховатий бір & $0,140 \pm 0,131$ & $0,047-0,299$ \\
\hline \multirow{2}{*}{ Маса винесеного грунту, кг/га } & степова цілинка & $171 * \pm 81,3$ & $80,6-322$ \\
\cline { 2 - 4 } & суховатий бір & $374 \pm 95,2$ & $92,7-802$ \\
\hline
\end{tabular}

Примітка. М - середнє значення, SD - стандартне відхилення, * - $\mathrm{P}<0,05$.

При перерахуванні обсягів рийної активності ящірок на 1 гектар виявилося, що загальний об'єм винесеного грунту у двох досліджуваних біогеоценозах майже однаковий. У той же час маса винесеного ящірками на поверхню грунту майже у два рази більша у суховатому бору (табл. 2).

Висновки. Встановлено, що нори прудкої ящірки в степових та лісових біогеоценозах Присамар'я дещо відрізняються за будовою. За довжиною ходу та глибиною риття нір відмінностей між двома типами екосистем не виявлено. Але об'єм та маса грунту, який виноситься з однієї нори на поверхню, більші у суховатому бору на 20 \% та 280 \% відповідно. Однак у перерахунку на гектар, з урахуванням щільності нір в екосистемах, лише маса винесеного грунту достовірно більша в лісовій екосистемі (в 2,2 раза).

Слід зазначити, що у порівнянні із гризунами та навіть часниковою жабою (В. Л. Булахов, О. С. Пахомов, 2010) обсяги рийної діяльності прудкої ящірки незначні, але вона робить свій постійний внесок у процеси педогенезу екосистем.

\section{Бібліографічні посилання}

1. Алексеев Ю. Е., Бельгард А. Л., Губанов И. А. Растительный и почвенный покров Присамарья Днепровского. Днепропетровск. 1986. 63 с. 
2. Белова Н. А., Травлеев А. П. Естественные леса и степные почвы (экология, микроморфология, генезис). Днепропетровск. 1999. 348 с. $264 \mathrm{c}$.

3. Бельгард А. Л. Лесная растительность юго-востока Украинской ССР. Киев. 1950.

4. Бельгард А. Л. Степное лесоведение. Москва. 1971.336 с.

5. Булахов В. Л., Гассо В. Я., Пахомов О. $\boldsymbol{C}$. Біологічне різноманіття України. Дніпропетровська область. Земноводні та плазуни (Amphibia et Reptilia). Дніпропетровськ. 2007. $420 \mathrm{c}$.

6. Булахов B. Л. Закономерности биогеоценотического распределения пресмыкающихся в различных типах степных лесов Центрального степного Приднепровья. Одесса. 2000. С. 183-188.

7. Булахов В. Л., Константинова Н. Ф. К морфобиологической характеристике Lacerta agilis L. в различных типах лесных биогеоценозов Присамарья // Вопр. степн. лесовед. Вып. 2. 1977. С. 91-96.

8. Булахов В. Л., Пахомов О. $\boldsymbol{G}$. Функціональна зоологія: підручник. Дніпропетровськ. 2010. 392 с.

9. Гассо В. Я. Біогеоценотичні особливості розподілу плазунів в умовах степових лісів Присамар'я Дніпровського // Екологія та ноосферологія. 2009. Т. 20. № 3-4. С. 102109.

10. Грицан Ю. І. Екологічні основи перетворюючого впливу лісової рослинності на степове середовище. Дніпропетровськ. 2000. 300 с.

11. Гончарова В. П. Об амфибиях и рептилиях Самарского леса // Матер. к научн.итог. конф. Днепропетр. гос. ун-та. Днепропетровск. 1961. С. 59-60.

12. Кармишев Ю. В. Плазуни півдня степової зони України: автореф. дис. на здобуття наук. ступеня канд. біол. наук. Київ. 2002. 20 с.

13. Новиков $\boldsymbol{\Gamma}$. $\boldsymbol{A}$. Полевые исследования экологии наземных позвоночных животных. Москва. 1949. 145 с.

14. Прыткая ящерица. Монографическое описание вида / под ред. А. В. Яблокова. Москва. 1976. $376 \mathrm{c.}$

15. Таращук В. I. Земноводні та плазуни // Фауна України. Т. 7. Київ. 1959. 246 с.

16. Физико-географическое районирование Украинской ССР. Киев. 1968. 684 с.

17. Фізична та економічна географія Дніпропетровської області. Дніпропетровськ. 1992. $188 \mathrm{c}$.

18. Vitt L. J., Caldwell J. P. Herpetology: an introductory biology of amphibians and reptiles. Academic Press. 2013. 776 p.

Надійшла до редколегії 24.07.2016

УДК 634.41

А. Ф. Кулік

Дніпропетровський національний університет імені Олеся Гончара

\section{ДИНАМІКА БІОЛОГІЧНОЇ АКТИВНОСТІ ГРУНТІВ ЛІСОВИХ БІОГЕОЦЕНОЗІВ ПРИСАМАР'Я}

Представлено результати досліджень одного з показників біологічної активності грунтів - вміст вуглекислого газу, що характеризує інтенсивність дихання у грунтах. Встановлено, що біологічна активність грунтів досліджуваних насаджень Quercus robur L. наближувалася до активності у природних лісових біогеоценозах і залежала від сезонної динаміки, типу лісорослинних умов, типу деревостану, вологості та ін.

Ключові слова: біогеоценози, лісові насадження, грунти, вміст вуглекислого газу, сезонна динаміка.

(C) А. Ф. Кулік, 2016 